\title{
Spindle Cell Rhabdomyosarcoma Displaying CD34 Positivity: A Potential Diagnostic Pitfall; Report of Two Pediatric Cases
}

\section{CD34 Pozitivitesi Gösteren İğsi Hücreli Rabdomyosarkoma: İki Pediatrik Tuzak Olgunun Sunumu}

\author{
Ayper KAÇAR' ${ }^{\text {, Hacı Ahmet DEMIR², Haydar DURAK³ }}$, Sergülen DERVişOĞLU³ \\ Department of 'Pathology, ${ }^{2}$ Oncology, Ankara Child Health and Diseases Hematology Oncology Training and Research Hospital, ANKARA, TURKEY \\ ${ }^{3}$ Department of Pathology, Istanbul University, Cerrahpaşa Faculty of Medicine, ISTANBUL, TURKEY
}

\begin{abstract}
Spindle cell rhabdomyosarcoma is a rare subtype of rhabdomyosarcoma mainly seen in children. Occasional aberrant staining with a variety of immunohistochemical markers has been noted. The aberrantly expressed markers include alpha-smooth muscle actin, cytokeratin, S100, neurofilaments, CD20, immunoglobins, and CD117.

We report herein two pediatric cases displaying strong CD34 positivity and one with additional focal CD117 positivity, causing considerable difficulty in distinction from solitary fibrous tumor and extra-gastrointestinal stromal tumor.

To our knowledge, CD34 staining has been merely reported in rhabdomyosarcoma. Spindle cell rhabdomyosarcoma has to be considered in the differential diagnosis of childhood spindle cell tumors. Post-chemotherapy specimens should be evaluated in caution, since chemotherapy can cause considerable changes in tumor antigen expression. Since CD117 and CD34 are stem cell markers, their positivity in pediatric tumors should be interpreted with caution. Even if the morphology is not supportive, a wide immunohistochemical panel should be applied in childhood malignant solid tumors.
\end{abstract}

Key Words: Rhabdomyosarcoma, Antigens, CD34, Differential diagnosis
ÖZ

İğsi hücreli rabdomyosarkoma temel olarak çocuklarda gözlenen bir rabdomyosarkom alt tipidir. Bu tümörlerde çeşitli immünohistokimyasal belirteçlerin aberran boyanma gösterebildiği bilinmektedir. Başlıca aberran boyanan belirteçler alfa düz kas aktini, sitokeratin, S100, nörofilaman, CD20, immünglobinler ve CD117’ dir.

Biz bu makalede biri CD117 pozitivitesi de gösteren, kuvvetli CD34 ekspresyonuna sahip, soliter fibröz tümör ve ekstra gastrointestinal stromal tümör ile ayırıcı tanı güçlüğü yaratan 2 pediatrik tuzak olguyu sunuyoruz.

Bildiğimiz kadarıyla rabdomyosarkomda CD34 pozitivitesi nadiren raporlanmıştır. İğsi hücreli rabdomyosarkoma çocukluk çağı iğsi hücreli tümörlerinin ayırıcı tanısında dikkate alınmalıdır. Kemoterapi sonrasına ait materyallerde tümör antijen ekspresyonuna ait değişiklikler olabileceğinden, dikkatli değerlendirilmelidir. CD117 ve CD34 kök hücre belirteçleri olduğundan pediatrik tümörlerde dikkatli değerlendirilmelidir. Çocukluk çağı solid tümörlerinde morfoloji düșündürmese bile immünohistokimyasal panel geniș tutulmalıdır.

Anahtar Sözcükler: Rabdomyosarkoma, Antijenler, CD34, Ayırıc1 $\tan 1$

This initial system depended purely on morphologic features, without the benefit of immunohistochemical or genetic confirmation. Following various modifications of the classic Horn-Enterline system, Newton et al. (3) proposed a new classification for RMSs that modified the Horn-Enterline system and incorporated portions of the newer schemata (Table I). It should be noted that botryoid and SCRMSs are currently considered to be variants of embryonal RMSs, and no inherent biologic differences have been identified to date.

Correspondence: Ayper KAÇAR

Ordu Üniversitesi Tıp Fakültesi Patoloji Anabilim Dalı, ORDU, TURKEY

E-mail: ayperkacar@yahoo.com Phone: +90 4522250190 
Table I: International classification of rhabdomyosarcoma

\begin{tabular}{|l|l|l|}
\hline Superior Prognosis & Intermediate Prognosis & Poor Prognosis \\
\hline Botryoid rhabdomyosarcoma & Embryonal rhabdomyosarcoma & Alveolar rhabdomyosarcoma \\
\hline Spindle cell rhabdomyosarcoma & & Undifferentiated sarcoma \\
\hline
\end{tabular}

The differential diagnosis of RMS includes two categories: the small round cell tumors of childhood and myogenic tumors of various types. SCRMSs may pose a problem because of their resemblance to other spindle cell neoplasms, notably fibroblastic and peripheral nerve sheath tumors. We report herein two cases displaying diffuse CD34 positivity and one with additional focal CD117 positivity, resulting in confusion with solitary fibrous tumor (SFT) and extra-gastrointestinal stromal tumor (GIST) and causing considerable difficulty in diagnosis.

It is hoped that this case report will expand the literature on pediatric SCRMS and alert pathologists to the possible diagnostic challenge of distinguishing between SCRMS and its spindle cell mimics and the relatively frequent expression of CD34 in childhood tumors.

\section{CASES}

\section{Case 1}

A 9-year-old boy presented with left facial swelling, pain and ptosis. A heterogeneous left parapharyngeal mass filling the infratemporal fossa and rimming the sinus cavernosus was detected in computerized tomography (CT). An incisional biopsy was diagnosed initially as primitive neuroectodermal tumor (ganglioneuroblastoma). The case was sent to

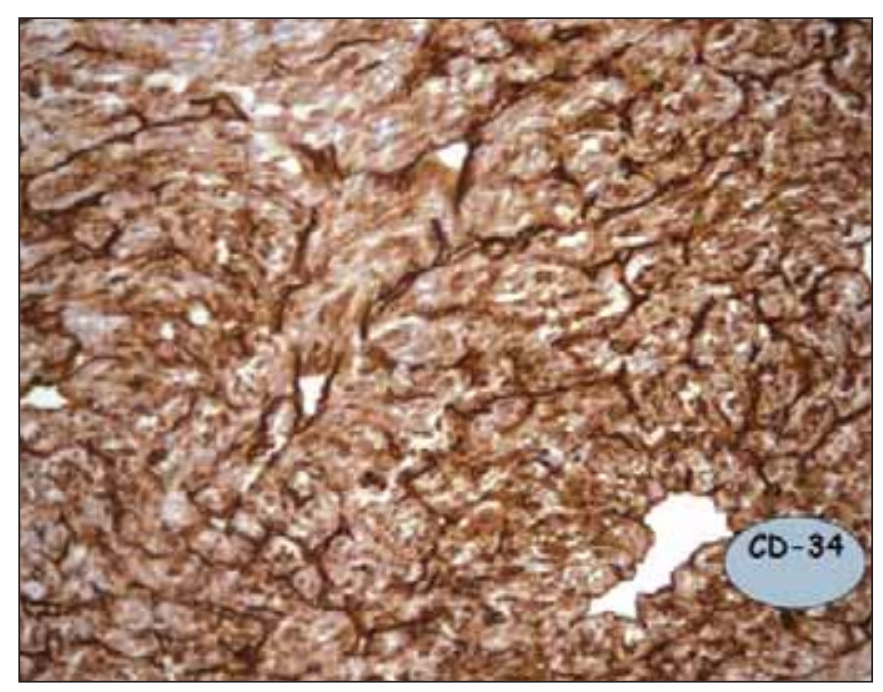

Figure 1: Strong CD34 positivity of the vessels and tumor stroma (x200). another center for further explorations. Angiofibroma, RMS and lymphoma were considered in the differential diagnosis clinically. Pathologic review of the slides showed a cellular, mitotically active (8/10 high-power field [HPF]) spindle cell tumor without necrosis. CD34 staining revealed prominent hemangiopericytomatous pattern and diffuse positivity of the tumor cells for this marker (Figure 1). Bcl2 showed weakly positive cytoplasmic staining pattern and S100 was negative. The lesion was reported to be consistent with malignant hemangiopericytoma. The tumor was extirpated according to a left midfacial degloving technique one month later. Since the tumor was found to be expanding intracranially, only a subtotal excision was possible during the operation. Because of the rapid expansion of the mass (5.5 $\mathrm{cm}$ infiltrative mass) detected on the 5th day after the operation, an RMS chemotherapy protocol was clinically started on that date.

Recurrence of the lesion occurred two years later and he was re-operated. Pathologically, a cellular spindle cell tumor with prominent hemangiopericytomatous pattern was noted (Figure 2). The tumor showed focal post-chemotherapy maturated areas displaying mature rhabdomyoblastic differentiation (Figure 3). Immunohistochemically, the tumor showed diffuse positive staining for desmin, and

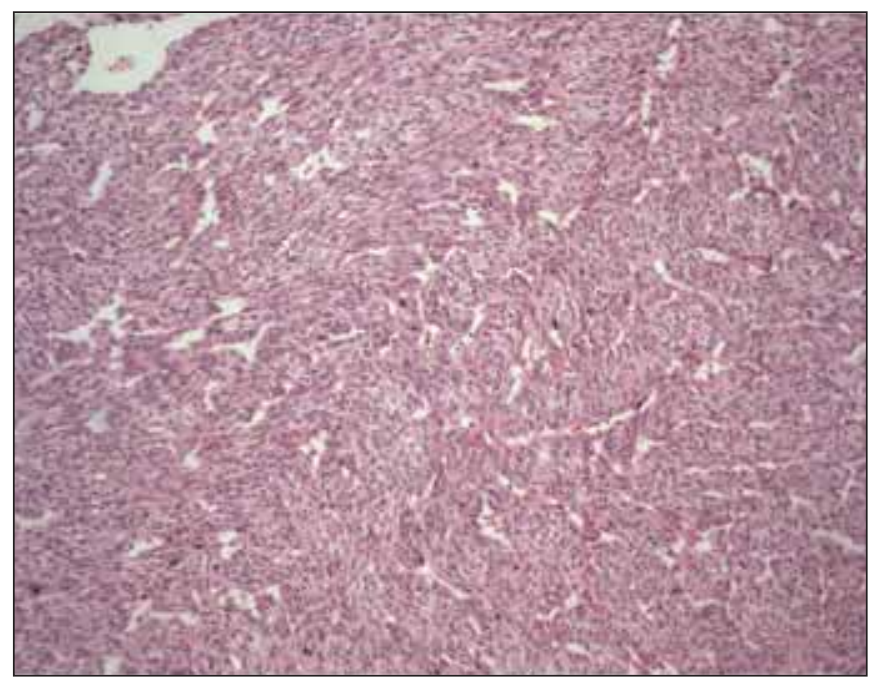

Figure 2: Recurrence of the lesion with prominent hemangiopericytomatous pattern (x100, H\&E). 
focally for CD34 (40\% of the cells) and myogenin (Figure $4,5)$. Bcl-2 and CD99 were negative. The tumor was diagnosed as SCRMS on the basis of clinical, morphologic and immunohistochemical findings.

\section{Case 2}

A 2.5-year-old boy presented with an abdominal mass, which was shown by $\mathrm{CT}$ as originating from the vesical column and infiltrating the posterior abdominal wall. A tru-cut biopsy revealed a mitotically active spindle cell tumor that was positive for desmin (focally) and vimentin and negative for alpha-smooth muscle actin (aSMA), epithelial membrane antigen (EMA) and leukocyte common antigen (LCA). On the basis of morphologic and immunohistochemical features, a possible muscular

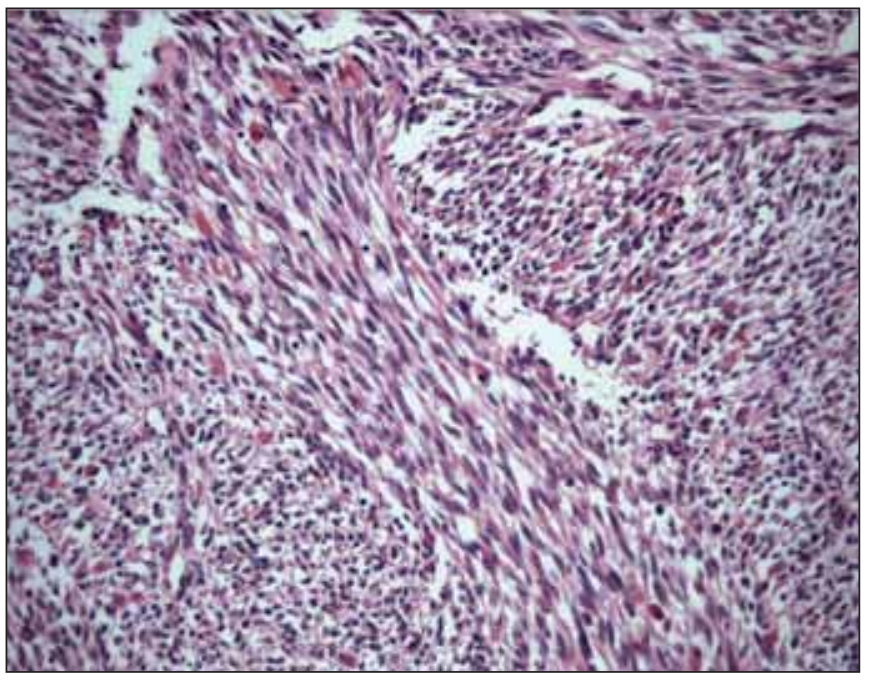

Figure 3: Recurrent tumor displaying focal mature rhabdomyoblastic differentiation (x200, H\&E).

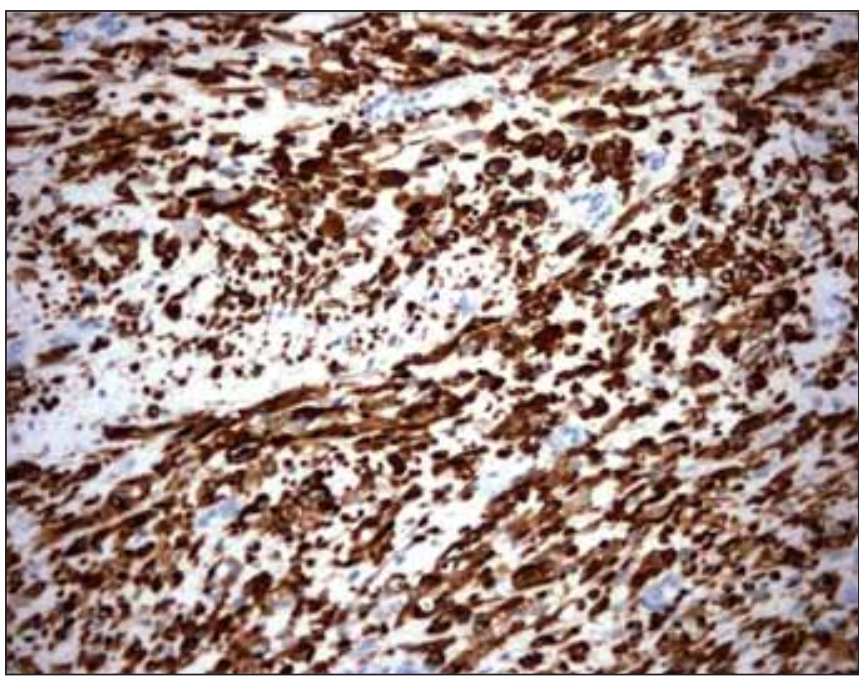

Figure 4: Desmin positivity (x400). origin was suggested. The patient underwent resection following RMS chemotherapy protocol four months later. Histopathologically, the excision material showed a spindle cell tumor with diffuse positivity for vimentin and CD34 (monoclonal mouse, Dako ready-to-use N-series, N1632), and focal positivity for desmin, CD117 and S100. MyoD1, EMA, CK (wide spectrum [w.s.]), aSMA, and CD68 were negative and the proliferation index with Ki67 was below $2 \%$. The case was reported as extra-GIST based on these findings.

The patient was referred to Ankara Children's Hematology Oncology Hospital with recurrence of the retrovesical mass 10 months later. The histologic slides from the original excision were reviewed in our department with a wide immunohistochemical panel. Nine paraffin blocks from the resection and 1 paraffin block of the initial Tru-cut biopsy were available for consultation. Hematoxylin-eosin (H\&E) preparations from the initial Tru-cut biopsy revealed a mitotically active (1-3/HPF) cellular spindle cell tumor. One of the nine blocks obtained from the post-chemotherapy resection material showed diffuse rhabdomyoblastic differentiation without spindle cell component (Figure 6), and others were compatible with a mitotically inactive (Ki67 proliferation index $<2 \%$ ) spindle cell tumor with hypocellular myxoid and hypercellular areas displaying storiform pattern and intercellular collagen (Figure 7). No mature rhabdomyoblast-like cells were noted in the rest of the lesion. The tumor showed diffuse strong positivity for vimentin and CD34 (Figure 8) and focal positivity for desmin (Figure 9) and CD117. aSMA, EMA, CD99, CK (AE1AE3), and myosin were negative. Histopathologic differential diagnosis included RMS, SFT, low-grade fibromyxoid

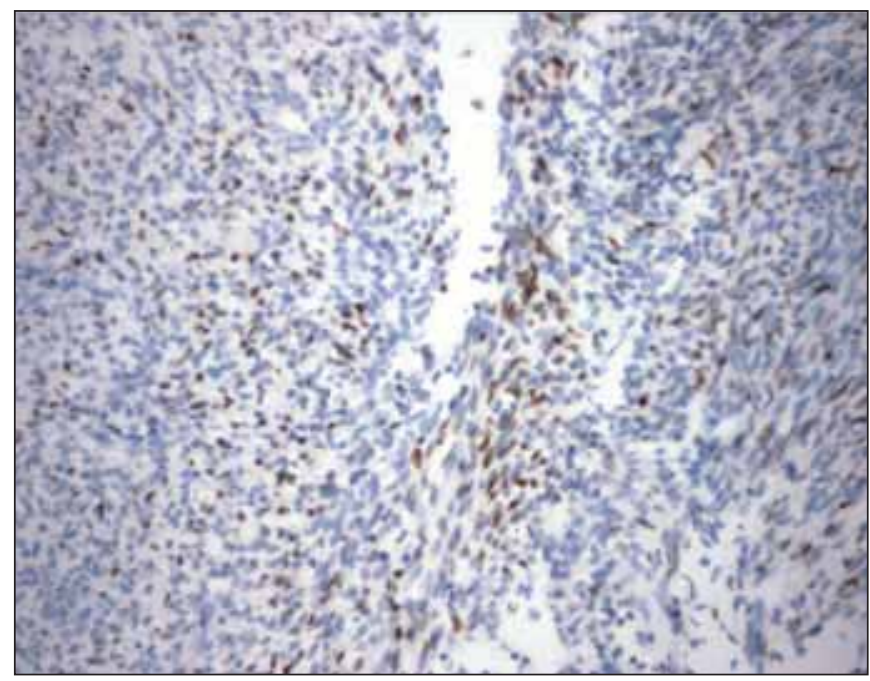

Figure 5: Myogenin positivity (x200). 


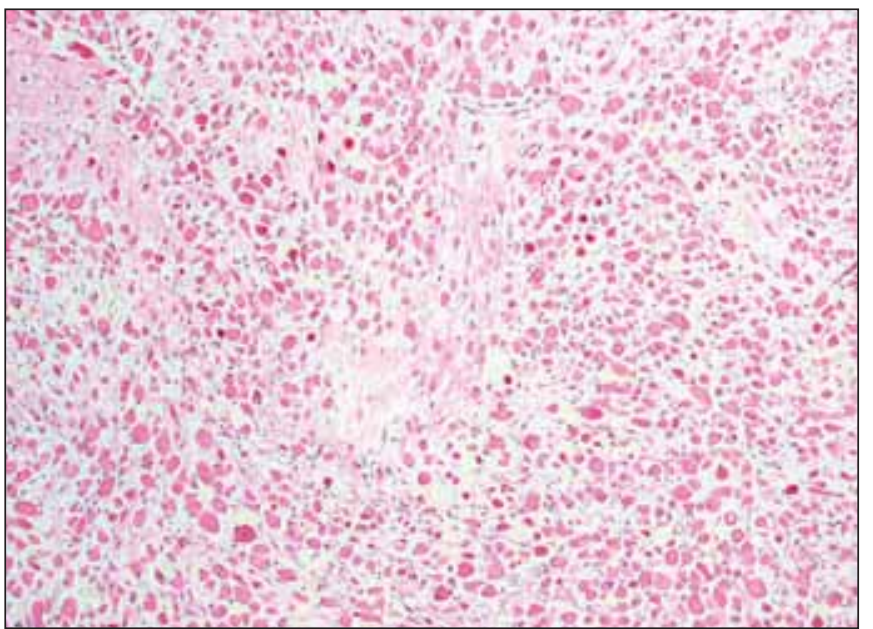

Figure 6: Isolated and pure rhabdomyoblastic differentiation area in the tumor (x100, H\&E).

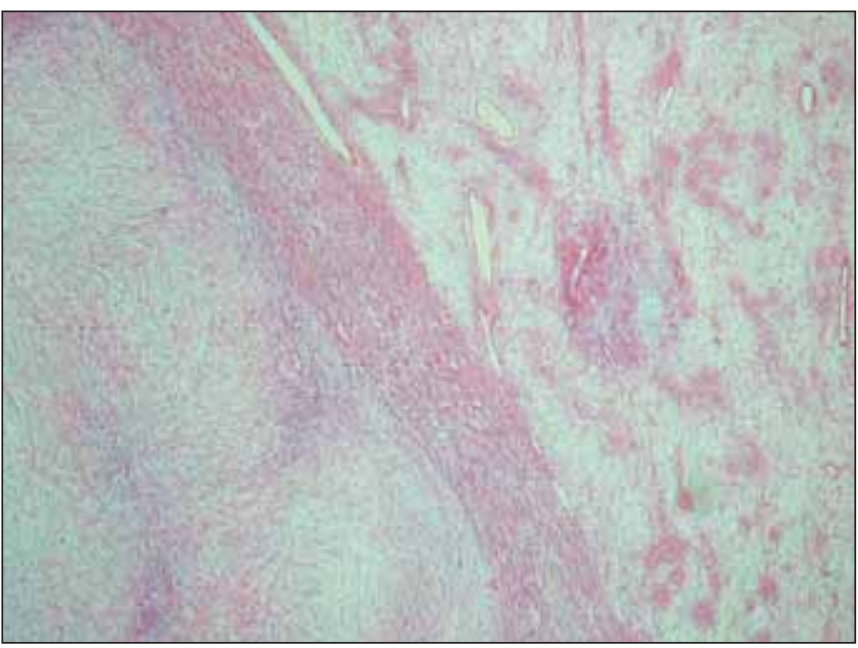

Figure 7: Tumor areas showing hypocellular myxoid areas adjacent to hypercellular areas displaying storiform pattern and intercellular collagen (x100, H\&E).

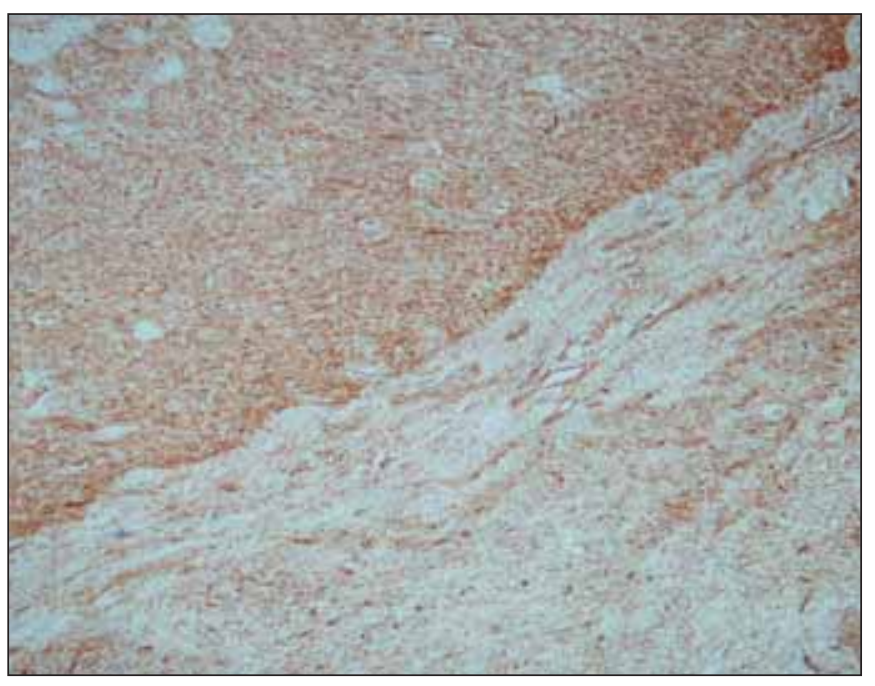

Figure 8: Strong and diffuse CD34 positivity (x100).

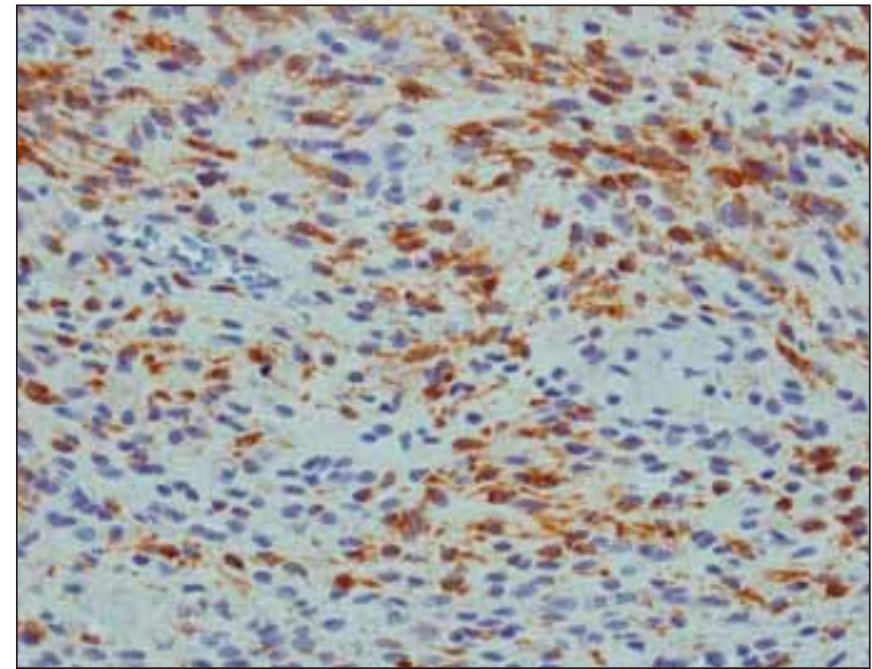

Figure 9: Cytoplasmic desmin positivity (x400).

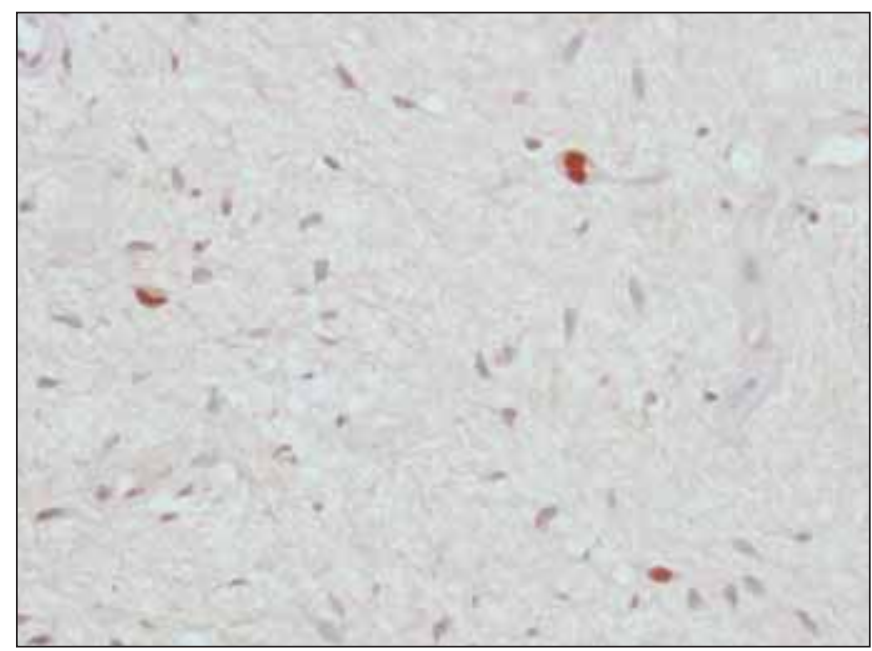

Figure 10: Nuclear myogenin positivity (x400).

sarcoma, infantile rhabdomyofibrosarcoma, extra-GIST, myxofibrosarcoma, and fetal rhabdomyoma. A myogenin staining revealed focal intense nuclear positivity for this marker (Figure 10). The patient received chemotherapy during the 8 months follow-up and had a good response.

\section{DISCUSSION}

Rhabdomyosarcomas (RMSs) constitute a unique group of soft tissue neoplasms that share a propensity to undergo myogenesis, a well-defined biological process that primarily occurs during embryonal and fetal development. A common misconception is that RMSs arise in skeletal muscle, but in fact, many pediatric examples arise in viscera such as the prostate, urinary bladder, and gall bladder, which are devoid of striated muscle fibers. However, certain subtypes typically arise in the extremities and likely originate from 
myoblasts, particularly those types associated with genetic fusions. The exact origin of extramyogenous RMSs is more problematic, because myogenic transformation can be induced in nonmuscle cells by genetic manipulation and might be reproduced via tumorigenic influences. Alternatively, origin from misplaced myotomic cells cannot be completely discounted. Another misconception is that RMSs represent a single tumor type, whereas there are distinct clinical, pathologic and molecular differences among at least three different variants (2).

Spindle cell rhabdomyosarcoma (SCRMS) comprised the other end of the cytologic spectrum for Palmer and Foulkes (4), being composed of elongated spindle cells arrayed in tight fascicles with variable amounts of intervening collagen, often reminiscent of leiomyosarcomas. Palmer also found their behavior to be converse, with a prognosis superior to that of typical embryonal RMS. A group of these lesions was consequently described by Cavazzana et al. (5), who confirmed their superior prognosis and found that the majority occurred in the paratesticular region. Table II shows the frequent anatomic sites of this tumor (1).

The differential diagnosis of RMS includes two categories: the small round cell tumors of childhood and myogenic tumors of various types. SCRMSs may pose a problem because of their resemblance to other spindle cell neoplasms, notably fibroblastic and peripheral nerve sheath tumors. However, they should be sufficiently cellular, mitotically active and atypical to not be confused with benign proliferations. Desmin and actin stains may be misleading in fibroblastic lesions because they are also expressed in myofibroblasts. MyoD and myogenin are the most useful markers in the differential diagnosis. SCRMSs are noted to present strong expression for myogenic antigens (muscle-specific antigen [MSA] and desmin). Late-period myogenic antigens like titin and troponin $\mathrm{D}$ are known to have wider expression in this subtype compared with the others (1).

Table II: Anatomic distribution of spindle cell rhabdomyosarcoma (SCRMS)

\begin{tabular}{|l|c|c|}
\hline Anatomic location & No. & \% \\
\hline Paratesticular & 30 & 38 \\
\hline Head and neck & 21 & 27 \\
\hline Extremities & 8 & 10 \\
\hline Genitourinary & 8 & 10 \\
\hline Total & 78 & 100 \\
\hline
\end{tabular}

Occasional aberrant staining with a variety of immunohistochemical markers has been noted in RMS. The aberrantly expressed markers include aSMA, cytokeratin, S100, neurofilaments, CD20, immunoglobins, and CD117 (6). We have searched the English literature for the immunohistochemical features of SCRMS (Table III). Despite the fact that CD34 and CD117 were not tested frequently in the differential diagnosis of this tumor, CD34 was negative in two studies and CD117 was positive in one $(7,8,9)$.

A more profound research revealed some remarkable points on CD34 positivity in spindle cell tumors. In the study of Stock et al. (10), 57 cases of adult-type RMS were analyzed using immunohistochemistry, and the cases were classified into three histologic categories: SCRMS, pleomorphic RMS and mixed type. In their study, CD34 positivity was found in $13.2 \%$ of the cases, while desmin and myogenin were positive in every case. In another study, CD34 immunohistochemistry was applied to female genital tract carcinosarcoma (malignant mixed müllerian tumors), and it was noted that heterologous components consisting of RMS displayed staining with CD34 in some tumors (11). CD117 expression in SCRMS is also noted in very limited studies in the literature $(9,12)$.

In one study, staining for CD117 was strong in two of two SCRMSs, while no staining was detectable in two botryoid variants and 20 conventional embryonal RMSs (9).

In conclusion, we report two cases of SCRMSs that exhibit marked CD34 staining and cause diagnostic confusion by mimicking other fibrous tumors, including SFT/ hemangiopericytoma. Take home messages that could be derived from these two cases can be summarized as follows:

1. SCRMS has to be considered in the differential diagnosis of childhood spindle cell tumors.

2. The better differentiated areas in RMSs can be very isolated and focal; besides the well differentiated appearance of SCRMS that has been emphasized classically, could be not true for all cases.

3. Post-chemotherapy specimens should be evaluated in caution, since chemotherapy can cause considerable changes in tumor antigen expression.

4. Since CD117 and CD34 are stem cell markers, their positivity in pediatric tumors should be interpreted with caution.

5. Even if the morphology is not supportive, a wide immunohistochemical panel should be applied in childhood malignant solid tumors. 
Table III: Immunohistochemical features in spindle cell rhabdomyosarcoma (SCRMS)

\begin{tabular}{|c|c|c|c|c|c|}
\hline References & $\begin{array}{c}\text { Fraternali } \\
\text { Orcioni et al. (7) }\end{array}$ & Zhang et al. (13) & Mentzel et al. (8) & Diniz et al. (9) & Rubin et al. (14) \\
\hline Case no & 1 & 8 & 7 & 2 & 2 \\
\hline Vimentin & + & + & & & \\
\hline MSA & + & + & & & \\
\hline Desmin & + & + & $\mathrm{v}+$ & + & + \\
\hline Myogenin fast-Myosin & + & & $\mathrm{v}+$ & & \\
\hline Sarcomeric actin & $+/-$ & & & + & \\
\hline aSMA & - & & $+/$ - in 5 cases & & $+/-$ \\
\hline H-Caldesmon & - & & - & & \\
\hline CD34 & - & & - & & \\
\hline EMA & - & & - & & \\
\hline CK (w.s.) & - & - & - & & \\
\hline S100 & - & - & - & & - \\
\hline MyoD1 & & + & & & + \\
\hline Myoglobin & & + & & & + \\
\hline Plap & & - & & & \\
\hline CD117 & & - & & + & \\
\hline Fast-myosin & + & & + in 2 cases & & + \\
\hline WT1 & & & $\mathrm{v}+$ & & \\
\hline CD99 & & & $\mathrm{v}+$ & & \\
\hline
\end{tabular}

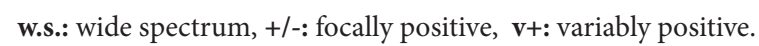

\section{REFERENCES}

1. Weiss SS, Goldblum JR: Enzinger and Weiss's Soft Tissue Tumors, 5th ed. Philadelphia, PA, Mosby Elsevier, 2008, 595-631

2. Parham DM, Ellison DA: Rhabdomyosarcomas in adults and children: An update. Arch Pathol Lab Med 2006, 130:1454-1465

3. Newton WA Jr, Gehan EA, Webber BL, Marsden HB, van Unnik AJ, Hamoudi AB, Tsokos MG, Shimada H, Harms D, Schmidt $D$ : Classification of rhabdomyosarcoma and related sarcomas: Pathologic aspects and proposal for a new classificationan Intergroup Rhabdomyosarcoma Study. Cancer 1995, 76: 1073-1085

4. Palmer NF, Foulkes M: Histopathology and prognosis in the second Intergroup Rhabdomyosarcoma Study (IRS II)[abstract]. Proc ASCO 1983, 2:229

5. Cavazzana AO, Schmidt D, Ninfo V, Harms D, Tollot M, Carli M, Treuner J, Betto R, Salviato G: Spindle cell rhabdomyosarcoma: A prognostically favorable variant of rhabdomyosarcoma. Am J Surg Pathol 1992, 16:229-235

6. Fletcher CDM, Unni KK, Mertens F: World Health Organization Classification of Tumors. Pathology and Genetics of Tumors of the Soft Tissue and Bone. Lyon, IARC Press, 2000, 146-152

7. Fraternali Orcioni G, Ravetti JL, Gaggero G, Bocca B, Bisceglia M: Primary embryonal spindle cell cardiac rhabdomyosarcoma: Case report. Pathol Res Pract 2010, 206:325-330
8. Mentzel T, Kuhnen C: Spindle cell rhabdomyosarcoma in adults: Clinicopathological and immunohistochemical analysis of seven new cases. Virchows Arch 2006, 449:554-560

9. Diniz G, Aktas S, Ortac R, Tunakan M, Unlu I, Vergin C: Kit expression in spindle cell rhabdomyosarcoma can possibly create a different approach for its tumorigenesis and therapy. Pathol Res Pract 2006, 202:671-677

10. Stock N, Chibon F, Binh MB, Terrier P, Michels JJ, Valo I, Robin YM, Guillou L, Ranchere-Vince D, Decouvelaere AV, Collin F, Birtwisle-Peyrottes I, Gregoire F, Aurias A, Coindre JM: Adult-type rhabdomyosarcoma: Analysis of 57 cases with clinicopathologic description, identification of 3 morphologic patterns and prognosis. Am J Surg Pathol 2009, 33:1850-1859

11. Costa MJ, Guinea D Jr: CD34 immunohistochemistry in female genital tract carcinosarcoma (malignant mixed müllerian tumors) supports a dominant role of the carcinomatous component. Appl Immunohistochem Mol Morphol 2000, 8:293-299

12. Smithey BE, Pappo AS, Hill DA: C-kit expression in pediatric solid tumors: A comparative immunohistochemical study. Am J Surg Pathol 2002, 26:486-492

13. Zhang HT, Guo L, Su Q: Clinicopathologic analysis of spindle cell rhabdomyosarcoma: Report of 8 cases. Zhonghua Zhong Liu Za Zhi 2008, 30:141-143

14. Rubin BP, Hasserjian RP, Singer S, Janecka I, Fletcher JA, Fletcher CD: Spindle cell rhabdomyosarcoma (so-called) in adults: Report of two cases with emphasis on differential diagnosis. Am J Surg Pathol 1998, 22:459-464 